\title{
Preliminary Results of a Randomized, Equivalence Trial of Fluoroscopic Caudal Epidural Injections in Managing Chronic Low Back Pain: Part 4 - Spinal Stenosis
}

Laxmaiah Manchikanti, MD¹, Kimberly A. Cash, RT ${ }^{1}$, Carla D. McManus, RN, BSN ${ }^{1}$, Vidyasagar Pampati, MSc', and Salahadin Abdi, MD, PhD²

From: ${ }^{1}$ Pain Management Center of Paducah, Paducah, $\mathrm{KY}$; and ${ }^{2}$ University of Miami, Miller School of Medicine, Miami, FL.

Dr. Manchikanti is Medical Director of the Pain Management Center of Paducah, Paducah, KY, and Associate Clinical Professor of Anesthesiology and Perioperative Medicine, University of Louisville, Louisville, KY.

Ms. Cash is a Research Coordinator at the Pain Management Center of Paducah, Paducah, KY.

Ms. McManus is a Nursing Administrator at the Pain Management Center of Paducah, Paducah, KY.

Mr. Pampati is a Statistician at the Pain Management Center of Paducah, Paducah, KY. Dr. Abdi is Professor and Chief,

Division of Pain Medicine, Department of Anesthesiology,

Perioperative Medicine and Pain Management, University of Miami, Miller School of Medicine, Miami, FL.

Address correspondence: Laxmaiah Manchikanti, MD 2831 Lone Oak Road

Paducah, Kentucky 42003 E-mail: drlm@thepainmd.com

Disclaimer: There was no external funding in the preparation of this manuscript.

Conflict of interest: None.

Manuscript received on: $10 / 17 / 2008$

Accepted for publication: $11 / 7 / 2008$

Free full manuscript: www.painphysicianjournal.com
Background: Spinal stenosis is one of the 3 most common diagnoses of low back and leg symptoms which also include disc herniation and degenerative spondylolisthesis. Spinal stenosis is a narrowing of the spinal canal with encroachment on the neural structures by surrounding the bone and soft tissue. In the United States, one of the most commonly performed interventions for managing chronic low back pain are epidural injections, including their use for spinal stenosis. However, there have not been any randomized trials and evidence is limited with regards to the effectiveness of epidural injections in managing chronic function-limiting low back and lower extremity pain secondary to lumbar spinal stenosis.

Study Design: A randomized, double-blind, equivalence trial.

Setting: An interventional pain management practice, a specialty referral center, a private practice setting in the United States.

Objectives: To evaluate the effectiveness of caudal epidural injections with or without steroids in providing effective and long-lasting pain relief in the management of chronic low back pain in spinal stenosis and to evaluate the differences between local anesthetic with or without steroids.

Methods: Patients were randomly assigned to one of 2 groups, with Group I patients receiving caudal epidural injections of local anesthetic (lidocaine 0.5\%), whereas Group II patients received caudal epidural injections with $0.5 \%$ lidocaine $9 \mathrm{~mL}$ mixed with $1 \mathrm{~mL}$ of steroid. Randomization is being performed by computer-generated random allocation sequence by simple randomization.

Outcomes Assessment: Multiple outcome measures were utilized which included the Numeric Rating Scale (NRS), the Oswestry Disability Index 2.0 (ODI), employment status, and opioid intake with assessment at 3 months, 6 months, and 12 months post-treatment.

Significant pain relief was defined as $50 \%$ or more, whereas significant improvement in disability score was defined as reduction of $40 \%$ or more.

Results: Significant pain relief ( $\geq 50 \%$ ) was demonstrated in $55 \%$ to $65 \%$ of the patients and functional status improvement with 40\% reduction in ODI scores in 55\% to $80 \%$ of the patients. The overall average procedures per year were $3.4 \pm 1.27$ in Group I and $2.6 \pm 1.35$ in Group II with an average total relief per year of $30.3 \pm 19.49$ weeks in Group I and $23.1 \pm 21.36$ weeks in Group II over a period of 52 weeks.

Limitations: The results of this study are limited by the lack of a placebo group and a preliminary report of 20 patients in each group, even though sample was justified.

Conclusion: Caudal epidural injections with or without steroids may be effective in patients with chronic function-limiting low back and lower extremity pain with spinal stenosis in approximately $60 \%$ of the patients.

Key words: Low back pain, lower extremity pain, spinal stenosis, epidural injections, steroids, local anesthetics

CLINICAL TRIAL: NCT00370799

Pain Physician 2008; 11:6:833-848 
ntervertebral disc herniation, spinal stenosis, and degenerative spondylolisthesis with stenosis are the 3 most common diagnoses of low back and leg symptoms for which surgery is performed $(1,2)$. Spinal stenosis is a narrowing of the spinal canal with encroachment on the neural structures by surrounding bone and soft tissue, with patients typically presenting with radicular leg pain or with neurogenic claudication (pain in the buttocks or legs with walking or standing that resolves with sitting down or lumbar flexion) (3). Although the incidence and prevalence of symptomatic lumbar spinal stenosis have not been established, it is the most frequent indication for spinal surgery in patients older than 65 years of age (4-7), and a report from the U.S. Agency for Healthcare Research and Quality (AHRQ) suggested that $13 \%$ to $14 \%$ of patients who see a spine specialist for low back complaints may have severe enough bony stenosis requiring surgical decompression (8). Further, very little is known about patients with lesser degrees of symptomatic stenosis and the natural history and prognosis of lumbar spinal stenosis. However, radiographic evidence of stenosis is frequently asymptomatic; thus, careful clinical correlation between symptoms and imaging is critical $(9,10)$. No doubt the diagnosis of spinal stenosis has improved with modern imaging modalities, but providing the best and most appropriate care for each patient is based on symptoms and functional disability. There are also studies which support that pain and function of patients with lumbar spinal stenosis remain unchanged in a majority of patients (11-14).

Most studies evaluating the treatment of spinal stenosis are related to surgery. A 2005 Cochrane review found that the paucity and heterogenicity of evidence limited the conclusions regarding surgical efficacy for spinal stenosis (15). The trials comparing surgical with non-surgical treatments were generally small and involved patients, both with and without degenerative spondylolisthesis $(3,11,13,16-19)$. Weinstein et al (3) as part of Spine Patient Outcomes Research Trial (SPORT) reported on 2-year outcomes of patients with spinal stenosis without degenerative spondylolisthesis to analyze the relative efficacy of surgical versus non-surgical treatment. They concluded that in the combined as-treated analysis, patients who underwent surgery showed significantly more improvement in all primary outcomes than did patients who were treated non-surgically. Further, a subgroup of patients with persistent, severe pain and progressive neural dysfunction have been reported to benefit from decompressive surgery even though the outcomes after surgery slowly deteriorate over time $(13,14,20-24)$.

In the United States, one of the most commonly performed interventions for managing chronic low back pain are epidural injections, including their use for spinal stenosis (25-33). Friedly et al (28) showed lumbar epidural injections were administered in $23 \%$ of patients with spinal stenosis with an additional $11 \%$ in patients with degenerative changes. Friedly et al (29) also showed a significant proportion of epidural injections with repeat procedures in the Department of Veteran's Affairs (VA) population.

Multiple approaches are available to access the epidural space in the lumbosacral spine include caudal and interlaminar or transforaminal. Evidence for managing the pain of spinal stenosis in the lumbar spine with caudal epidural injections has been limited, even though it is somewhat superior with caudal epidural injections compared to interlaminar epidural injections $(31,32)$. The technology assessment report in 2001 of the treatment of degenerative lumbar spinal stenosis by AHRQ (8) defined the general term spinal stenosis as being applicable to 3 root compression mechanisms or in combination including disc protrusion or herniation, osteitic overgrowth into the spinal canal or the foramina through which the roots pass laterally, and vertebral slippage or spondylolisthesis. This report showed that local anesthetic block provides temporary relief from neurogenic claudication for about one month. Further, this evaluation also showed that evidence for efficacy of other conservative treatments in lumbar spinal stenosis patients was lacking. This report also showed that there was evidence for patients to benefit more from surgery than conservative therapy if symptoms were severe. While the majority of the evidence has been derived from old studies for administering epidural steroids without fluoroscopy, several studies have been published evaluating spinal stenosis with studies performed under fluoroscopy, even though none of them have been randomized (34-38). Other studies without fluoroscopy also have been published (3944). Of the several fluoroscopically directed studies, 3 included caudal $(34,37,38)$, whereas 2 were caudal without fluoroscopy $(39,44)$. Botwin et al $(34)$ in a prospective evaluation evaluated 34 patients with bilateral radicular pain from lumbar spinal stenosis with 
fluoroscopically guided caudal epidural injections after failure of conservative care. They administered on average 2.2 injections per patient, all within 6 weeks of evaluation; $65 \%$ of the patients at 6 weeks, $62 \%$ at 6 months, and $54 \%$ at 12 months had a successful outcome, reporting at least greater than $50 \%$ reduction between pre-injection and post-injection visual analog scale (VAS). They also reported significant improvement in multiple other scores including sitting, standing, and satisfaction. Barre et al (37) in a retrospective evaluation of long-term efficacy of fluoroscopically guided caudal epidural steroid injections for lumbar spinal stenosis evaluated 80 patients receiving at least one caudal epidural steroid injection between 1995 and 2002 with an average of 1.6 epidural steroid injections administered. They reported an improvement on the NRS of $50 \%$ or greater in $35 \%$ of patients with a functional improvement of 2 points or greater in 36 patients on a long-term basis. Delport et al (38) in a retrospective outcome study reported the results of 140 patients, at or over the age of 55 years diagnosed with lumbar spinal stenosis, treated with either fluoroscopically guided transforaminal or caudal epidural steroid injections. Overall, they reported improvement of 2 months in 32\% with 39\% reporting less than 2 months of relief and with improvement in functional abilities in 53\%. Of these, 91 patients, or $65 \%$, received caudal epidural injections, whereas $59 \%$ of the patients received both. However, all 3 studies suffer from multiple flaws. Botwin et al (34) and Barre et al (37) both utilized one to 3 epidural injections within a short time period and expected persistent relief. Further, Delport et al (38) combined caudal and transforaminal epidural injections in multiple patients with a short-term follow-up. A series of 3 epidurals is an outdated procedural model, even though they utilized a contemporary approach with fluoroscopic utilization (30-32).

This study is undertaken to evaluate the role of caudal epidural injections in patients with chronic intractable pain secondary to spinal stenosis, with or without steroids. The study is designed to evaluate 120 patients. This preliminary report includes 40 patients completing one-year follow-up.

\section{Methods}

The study was conducted in an interventional pain management practice, a specialty referral center, in a private practice setting in the United States. The study was performed based on Consolidated Stan- dards of Reporting Trials (CONSORT) guidelines and an extension of the CONSORT statement reporting of non-inferiority and equivalence randomized trials (4547). The study protocol was approved by the Institutional Review Board (IRB) and was registered on the U.S. Clinical Trial Registry with an assigned number of NCT00370799.

\section{Participants}

Patients were assigned to one of 2 groups, with Group I patients receiving caudal epidural injections with injection of local anesthetic (lidocaine $0.5 \%$ ), whereas Group II patients received caudal epidural injections with $0.5 \%$ lidocaine $9 \mathrm{~mL}$ mixed with $1 \mathrm{~mL}$ of non-particulate betamethasone (Celestone). Each injection was a total volume of $10 \mathrm{~mL}(10 \mathrm{~mL}$ of lidocaine $0.5 \%$ or $9 \mathrm{~mL}$ of lidocaine with $1 \mathrm{~mL}$ of steroid), followed by $2 \mathrm{~mL}$ of $0.9 \%$ sodium chloride solution as a flush.

\section{Interventions}

All patients were provided with the IRB-approved protocol and the informed consent which described in detail all aspects of the study and withdrawal process.

\section{Pre-Enrollment Evaluation}

The pre-enrollment evaluation included demographic data, medical and surgical history with coexisting disease(s), radiologic investigations, physical examination, pain rating scores using the Numeric Rating Scale (NRS), work status, opioid intake, and functional status assessment by the Oswestry Disability Index 2.0 (ODI).

All patients with evidence of spinal stenosis and radicular pain were included. Patients without lower extremity pain were excluded.

\section{Inclusion Criteria}

Inclusion criteria were diagnosis of spinal stenosis with radicular pain, patients over the age of 50 years; patients with a history of chronic function-limiting low back pain and lower extremity pain of at least 6 months duration; and patients who were competent to understand the study protocol and provide voluntary, written informed consent and participate in outcome measurements.

Further inclusion criteria included patients who have failed to improve substantially with conservative management including, but not limited to physi- 
cal therapy, chiropractic manipulation, exercises, drug therapy, and bed rest.

Exclusion criteria were history of lumbar surgery, spinal stenosis without radicular pain, uncontrollable or unstable opioid use, uncontrolled psychiatric disorders, uncontrolled medical illness either acute or chronic, any conditions that could interfere with the interpretation of the outcome assessments, pregnant or lactating women, and patients with a history or potential for adverse reaction(s) to local anesthetics or steroids.

\section{Description of Interventions}

All caudal epidural procedures were performed by one physician in an ambulatory surgery setting, in a sterile operating room, under fluoroscopy, with patients in the prone position, under appropriate monitoring with intravenous access and sedation with midazolam and fentanyl. With sterile preparation, access to the epidural space was obtained, which was confirmed by injection of non-ionic contrast. Following this, injection $6 \mathrm{mg}$ of non-particulate betamethasone (either brand name or non-particulate) was carried out, followed by injection of $2 \mathrm{~mL}$ of $0.9 \%$ sodium chloride solution.

Repeat caudal epidural injections were provided based on the response to the prior caudal epidural injections evaluated by improvement in physical and functional status. Further, repeat caudal epidural injections were performed only when increased levels of pain were reported with deteriorating relief below $50 \%$.

\section{Additional Interventions}

All the patients underwent the treatments as assigned. A patient was unblinded on request or if an emergency situation existed. If a patient required additional caudal epidural injections, they were provided based on the response to the previous injections, either after unblinding or without unblinding. If the patient chose not to be unblinded, the prior treatment was repeated as assigned. However, if patients chose to be unblinded, they were offered either the assigned treatment or another treatment based on response. If the patients were non-responsive and different treatments other than caudal epidural injections were required, they were considered to be withdrawn from the study, and no subsequent data were collected. However, patients who were non-responsive and continued with conservative management were followed without further epidural injections with medical management, unless they requested unblinding. In addition, all patients who were lost to follow-up were considered withdrawn. Patients unavailable for follow-up were considered as lost-to-follow-up.

\section{Co-Interventions}

Most patients were receiving opioid and non-opioid analgesics, adjuvant analgesics, and some were involved in a therapeutic exercise program. If patients were improving significantly and the medical necessity for these drugs was lacking, medications were stopped or dosages were decreased. In addition, dosages were also increased, based on medical necessity. All patients continued previously directed exercise programs, as well as their work. Thus, in this study, there was no specific physical therapy, occupational therapy, bracing, or other interventions offered other than the study intervention.

\section{Objectives}

The study was designed to evaluate the effectiveness of caudal epidural injections with or without steroids in managing chronic low back pain with radiculitis secondary to spinal stenosis in providing effective and long-lasting pain relief and to evaluate the differences between local anesthetic with or without steroid.

\section{Outcomes}

Multiple outcome measures were utilized which included the NRS (0-10 scale) pain scale, the ODI on a 0-50 scale, employment status, and opioid intake in terms of morphine equivalents, with assessment at 3 months, 6 months, and 12 months post-treatment. The NRS represented no pain with a 0 and the worst pain imaginable with a 10 . The ODI was utilized for functional assessment. The value and validity of the NRS and ODI have been reported $(47,48)$. Thresholds for the minimum clinical important difference for the ODI varied from a 4 to 15 point change from a total score of 50. Significant pain relief was described as a $50 \%$ or more reduction in the NRS from baseline, whereas significant improvement in function was described as at least a $40 \%$ reduction in ODI (49-54).

Based on the dosage frequency and schedule of the drug, the opioid intake was converted into morphine equivalents (55). 
Employment and work status were determined based on employability at the time of enrollment rather than including all of the patients participating in the study as employable. Employment and work status were classified into multiple categories such as employable, housewife with no desire to work outside the home, retired, or over the age 65 . Patients who were unemployed due to pain or employed but on sick leave or laid off were considered as employable.

The epidurals were considered to be successful if a patient obtained consistent relief with the first and second procedures of at least one and 3 weeks respectively and if the relief from the second injection outlasted the first injection. All others were considered as failures.

\section{Sample Size}

Since there were no studies available for estimation of sample size for spinal stenosis with caudal epidural injections, it was calculated based on significant pain relief in lumbar disc herniation. Considering a 0.052 -sided significance level, a power of $80 \%$, and an allocation ratio of $1: 1,18$ patients in each group were estimated (56) and allowing for a $10 \%$ attrition/non-compliance rate, 40 subjects were required.

Previous studies of interventional techniques have confirmed that 50 to 60 patients is acceptable $(50-52,57)$.

\section{Randomization}

From a total of 120 patients, 60 patients are being randomly assigned into each group.

\section{Sequence Generation}

Randomization is being performed by computergenerated random allocations sequence by simple randomization.

\section{Allocation Concealment}

The operating room nurse assisting with the procedure randomized the patients and prepared the drugs appropriately.

\section{Implementation}

Participants were invited to enroll in the study if they met inclusion criteria. One of the 3 nurses assigned as coordinators of the study enrolled the par- ticipants and assigned participants to their respective groups.

\section{Blinding (Masking)}

Participants and those administering the interventions were blinded to the group assignment. The blinding was assured by mixing the patients with other patients receiving routine treatment and not informing the physician performing the procedure of the inclusion of the patients in the study. All the patients for one-year follow-up were selected by the statistician not participating in provision of patient care. The unblinding results were not disclosed to either the treating physician or other participants or patients. Thus, the nature of blinding was not interrupted.

\section{Statistical Methods}

Statistical analysis included chi-squared statistic, Fisher's exact test, t-test, and paired t-test. Results were considered statistically significant if the $P$ value was less than 0.05 .

Chi-squared statistic was used to test the differences in proportions. Fisher's exact test was used wherever the expected value was less than 5; a paired t-test was used to compare the pre- and post-treatment results of average pain scores and ODI measurements at baseline versus 3 months, 6 months, and 12 months. For comparison of mean scores between groups, t-test was performed.

\section{Intent-to-Treat-Analysis}

An intent-to-treat-analysis was performed. Either the last follow-up data or initial data were utilized in the patients who dropped out of the study and no other data were available.

\section{Results}

\section{Participant Flow}

Figure 1 illustrates the participant flow.

\section{Recruitment}

The recruitment period lasted from January 2007 to August 2008.

\section{Baseline Data}

Baseline demographic and clinical characteristics of each group are illustrated in Table 1. There were no significant differences noted between the groups. 


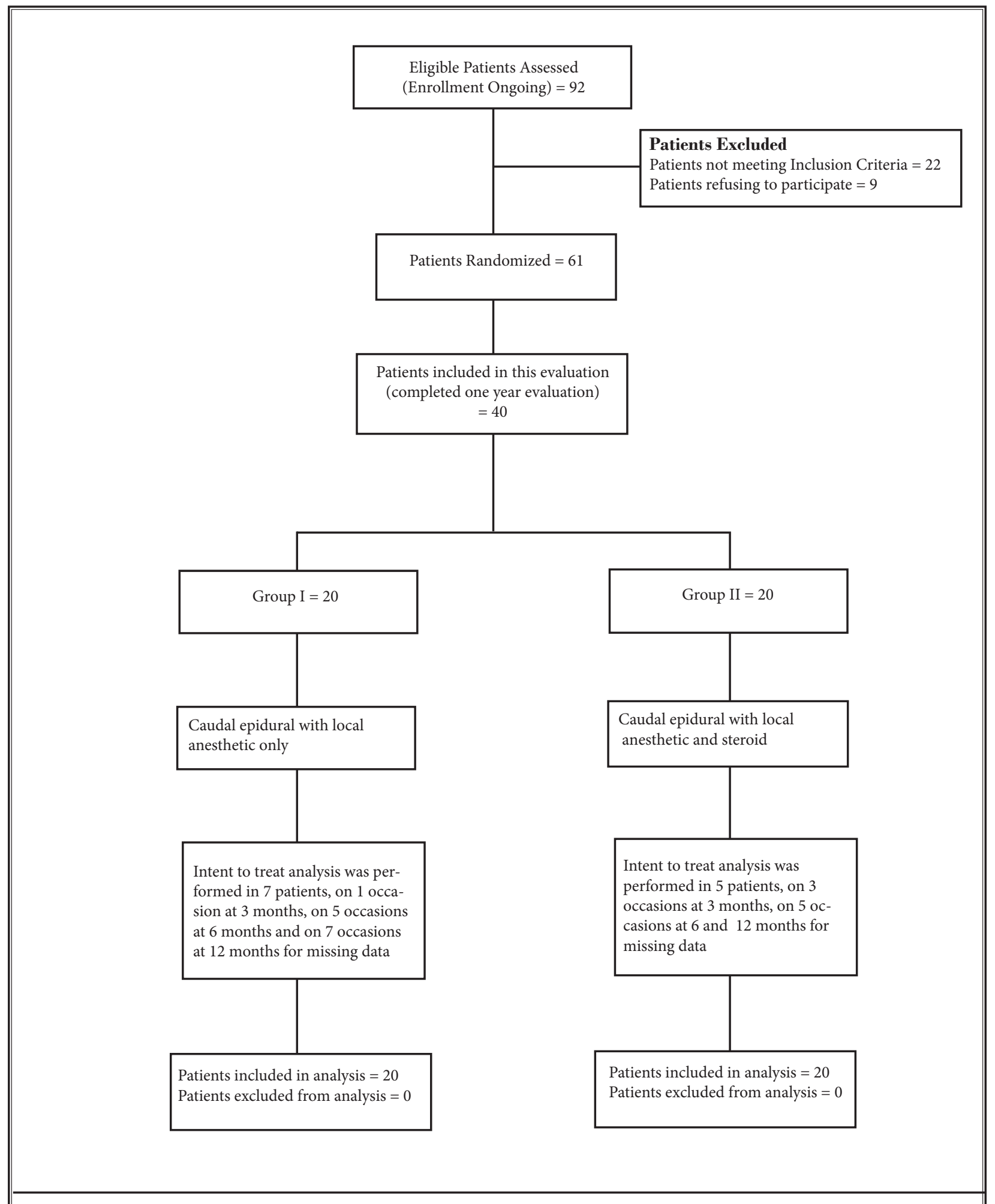

Fig. 1. Schematic presentation of patient flow at one-year follow-up. 
Table 1. Baseline demographic and clinical characteristics of participants.

\begin{tabular}{|c|c|c|c|c|}
\hline & & $\begin{array}{l}\text { Group } 1 \\
(n=20)\end{array}$ & $\begin{array}{l}\text { Group II } \\
(n=20)\end{array}$ & $P$ value \\
\hline \multirow{2}{*}{ Gender } & Male & $35 \%(7)$ & $25 \%(5)$ & \multirow{2}{*}{0.490} \\
\hline & Female & $65 \%(13)$ & $75 \%(15)$ & \\
\hline Age & Mean \pm SD & $60.3 \pm 17.37$ & $60.4 \pm 14.08$ & 0.976 \\
\hline Weight & Mean \pm SD & $186 \pm 55.15$ & $192 \pm 58.95$ & 0.741 \\
\hline Height & Mean \pm SD & $65.9 \pm 3.75$ & $66.1 \pm 3.41$ & 0.859 \\
\hline Duration of Pain (months) & Mean \pm SD & $84.5 \pm 66.23$ & $75.4 \pm 69.39$ & 0.672 \\
\hline \multirow{2}{*}{ Onset of the Pain } & Gradual & $75 \%(15)$ & $90 \%(18)$ & \multirow{2}{*}{1.000} \\
\hline & Injury & $25 \%(5)$ & $10 \%(2)$ & \\
\hline \multirow{2}{*}{ Low Back Pain Distribution } & Bilateral & $70 \%(14)$ & $70 \%(14)$ & \multirow{2}{*}{1.00} \\
\hline & Left or right & $30 \%(6)$ & $30 \%(6)$ & \\
\hline \multirow{2}{*}{ Leg pain Distribution } & Bilateral & $35 \%(7)$ & $25 \%(5)$ & \multirow{2}{*}{0.392} \\
\hline & Left or right & $65 \%(13)$ & $75 \%(15)$ & \\
\hline Numeric Pain Rating Score & Mean \pm SD & $8.1 \pm 1.00$ & $7.5 \pm 1.05$ & 0.098 \\
\hline Oswestry Disability Index & Mean \pm SD & $28.4 \pm 4.50$ & $26.1 \pm 4.63$ & 0.112 \\
\hline
\end{tabular}

\section{Analysis of Data}

\section{Numbers Analyzed}

A schematic illustration of patient flow is provided in Fig. 1. The study period for one-year follow-up lasted from January 2007 to August 2008 with completion of one-year follow-up of 40 patients with 20 patients in each group. Intent-to-treat analysis was performed due to non-available data on 13 occasions in Group I on a total of 7 patients, and on 13 occasions on 5 patients in Group II. Based on the number of follow-up periods, lack of follow-up was found in 13 of 60 occasions (9.3\%) in Group I or 7 of 20 patients; whereas it was 13 of 60 occasions in Group II with 5 of 20 patients at least one time.

\section{Outcomes}

\section{Pain Relief}

Figure 2 illustrates the NRS scores. Pain scores changed significantly from baseline, at 3 months, 6 months, and 12 months in all groups, with no significant differences between the groups or follow-up periods.

Figure 3 illustrates the proportion of patients with significant pain relief of $50 \%$ or greater at 3 months, 6 months, and 12 months, with $65 \%$ in Group I and 50\% in Group II at 3 months, $70 \%$ in Group I and $60 \%$ in Group II at 6 months, and $65 \%$ in Group I and 55\% in Group II at 12 months respectively. There were no significant differences between the groups or from the 3-month to 6-month to 12-month outcomes.

\section{Functional Assessment}

Functional assessment results assessed by the ODI are illustrated in Fig. 4. Significant improvement of functional status was seen in both groups from baseline to one year. Reduction of Oswestry scores of at least $40 \%$ was seen in $80 \%$ (Group I) and $55 \%$ Group II) at one-year as shown in Fig. 5 with no significant differences noted between the groups or during follow-up periods.

\section{Employment Characteristics}

Table 2 demonstrates employment characteristics in both groups. The number of eligible patients for employment at baseline remained the same at 12 months for both groups. The total employment was higher in both groups at 12 months; however, the differences were insignificant. 


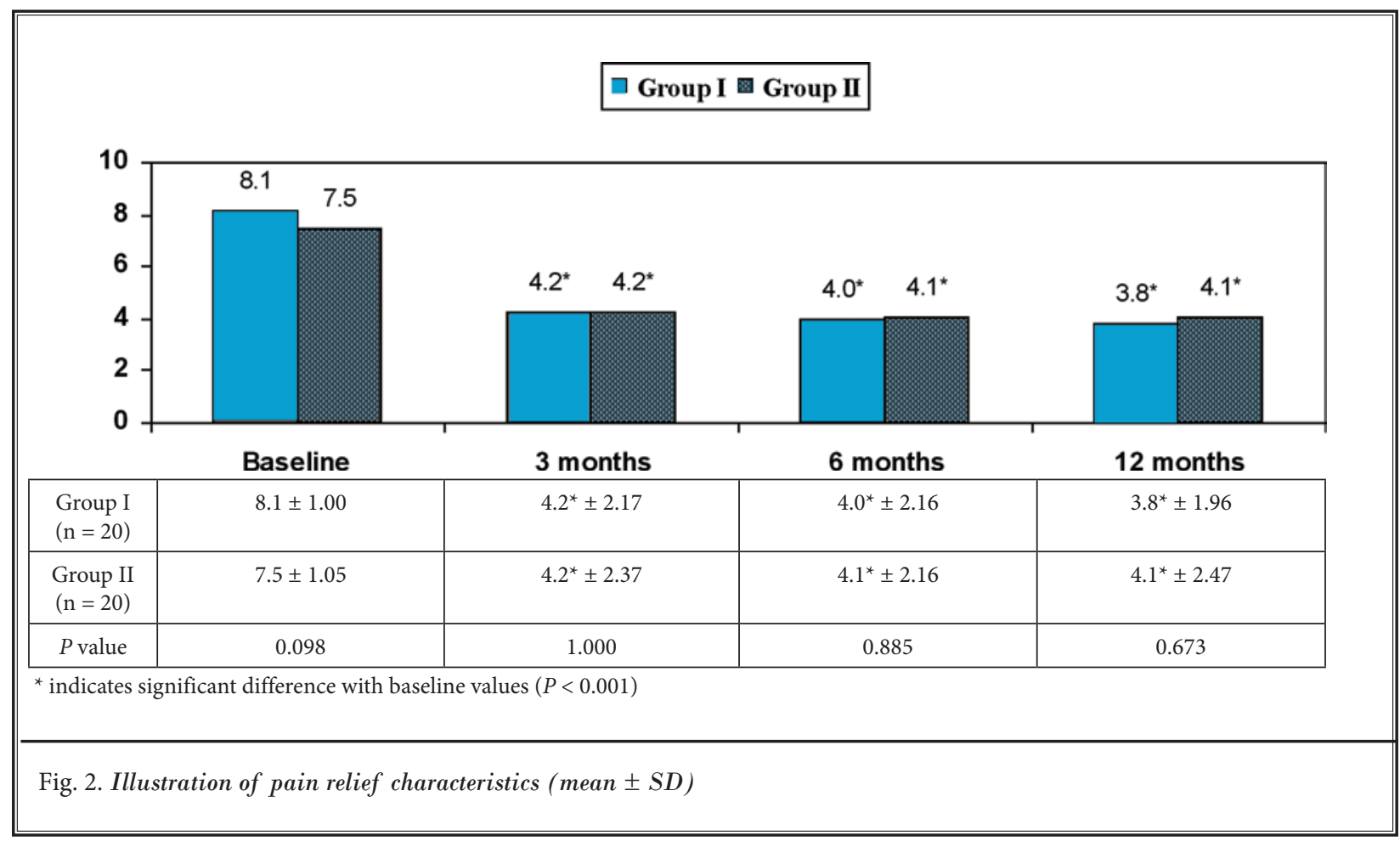

\begin{tabular}{|c|c|c|c|}
\hline \multirow{3}{*}{$\begin{array}{r}100 \% \\
80 \% \\
60 \% \\
40 \% \\
20 \% \\
0 \%\end{array}$} & & Group I 圆 Group II & \\
\hline & $65 \%$ & $70 \%$ & $65 \%$ \\
\hline & 3 months & 6 months & 12 months \\
\hline $\begin{array}{l}\text { Group I } \\
(\mathrm{n}=20)\end{array}$ & $65 \%(13)$ & $70 \%(14)$ & $65 \%(13)$ \\
\hline $\begin{array}{c}\text { Group II } \\
(\mathrm{n}=20)\end{array}$ & $50 \%(10)$ & $60 \%(12)$ & $55 \%(11)$ \\
\hline P value & 0.337 & 0.507 & 0.519 \\
\hline \multicolumn{4}{|c|}{ Fig. 3. Illustration of significant pain relief ( $\geq 50 \%$ reduction in Numeric Rating Score from baseline). } \\
\hline
\end{tabular}




\section{Group I 娄 Group II}

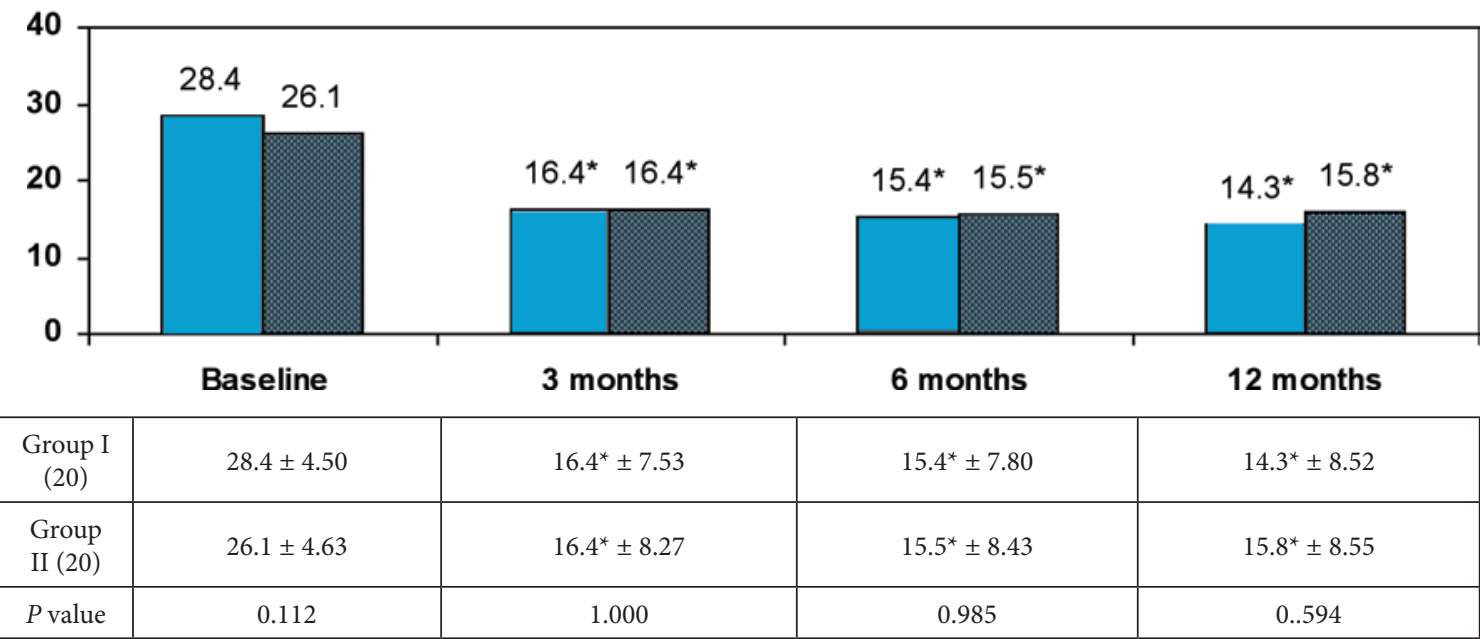

* indicates significant difference with baseline values $(P<0.001)$

Fig. 4. Illustration of average Oswestry Disability Index for functional assessment (scale 0-50\%).

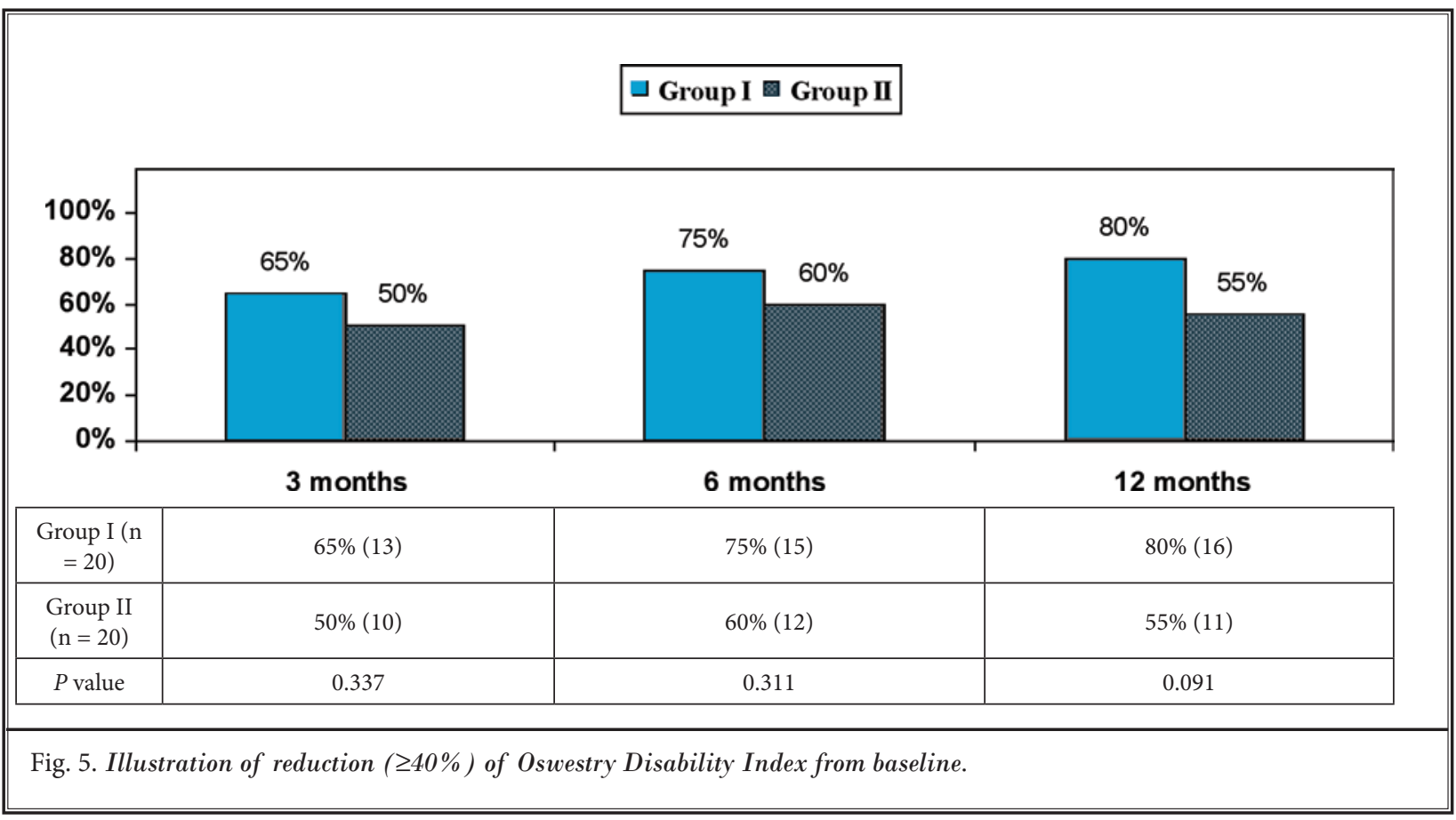


Table 2. Employment characteristics.

\begin{tabular}{|l|c|c|c|c|}
\hline \multirow{2}{*}{ Employment status } & \multicolumn{2}{|c|}{ Group I } & \multicolumn{2}{c|}{ Group II } \\
\cline { 2 - 5 } & Baseline & $\mathbf{1 2}$ months & Baseline & 12 months \\
\hline Employed part-time & 0 & 0 & 0 & 3 \\
\hline Employed full-time & 1 & 2 & 2 & 2 \\
\hline Unemployed/laid off/sick & 2 & 1 & $2(40 \%)$ & $3(60 \%)$ \\
\hline Total Employed & $1(33 \%)$ & $\mathbf{3}(67 \%)$ & $\mathbf{5}$ \\
\hline Eligible for employment & $\mathbf{3}$ & 2 & 5 & 5 \\
\hline Housewife with no desire to work outside & 2 & 8 & 4 & 4 \\
\hline Disabled & 8 & 7 & 6 & $\mathbf{2}$ \\
\hline Over 65 year of age & 7 & $\mathbf{2 0}$ & $\mathbf{2 0}$ \\
\hline Total Number of Patients & $\mathbf{2 0}$ & & $\mathbf{2 0}$ \\
\hline
\end{tabular}

Table 3. Daily opioid intake in morphine equivalents in milligrams.

\begin{tabular}{||l|c|c|c||}
\hline \multirow{2}{*}{ Opioid intake } & Group I (20) & Group II (20) & \multirow{2}{*}{ P value } \\
\cline { 2 - 3 } & Mean \pm SD & Mean \pm SD & 0.339 \\
\hline Baseline & $45.9 \pm 54.83$ & $33.3 \pm 36.87$ & 0.264 \\
\hline 3 months & $35.6 \pm 53.05$ & $21.2 \pm 18.87$ & 0.256 \\
\hline 6 months & $35.1 \# \pm 53.25$ & $20.5 \pm 19.09$ & 0.256 \\
\hline 12 months & $35.1 \# \pm 53.25$ & $20.5 \pm 19.06$ & 0 \\
\hline
\end{tabular}

\# indicates significant difference with baseline values $(P=0.05)$

\section{Opioid Intake}

Table 3 illustrates opioid intake between both groups at baseline and at 12 months that showed no significant change in intake of opioids. However, opioid intake significantly decreased from their baseline opioid intake in both groups at 12 months in Group I.

\section{Therapeutic Procedural Characteristics}

Therapeutic procedural characteristics with average pain relief per procedure are illustrated in Table 4. Average overall relief per year was $30.3 \pm 19.49$ weeks in Group I and $23.1 \pm 21.36$ weeks in Group II, with no significant differences. However, when patients were separated into successful and failed groups, the total number of injections per year was $3.8 \pm 1.21$ in Group I and $3.4 \pm 1.08$ in Group II for successful subjects with relief of $42.8 \pm 9.06$ weeks in Group I and $37.8 \pm 14.00$ weeks in Group II. In contrast, in failed subjects the number of injections per year was $2.6 \pm 0.98$ in Group
I and $1.4 \pm 0.52$ in Group II with average relief of $7.0 \pm$ 8.08 weeks in Group I and $1.0 \pm 2.14$ weeks in Group II.

Epidurals were considered to be successful if a patient obtained consistent relief with the first and second injections of at least one and 3 weeks respectively and if the relief with the second injection outlasted the first injection. All others were considered to be failures.

\section{Changes in Weight}

The weight was monitored for all the patients initially and also at one year. There was a mild reduction in weight in both groups with no significant differences noted (Table 5).

\section{Adverse Events}

There were no major adverse events reported over a period of one-year in any of the 40 patients. 
Table 4. Illustration of procedural characteristics with procedural frequency, average relief per procedure, and average total relief in weeks over a period of one year.

\begin{tabular}{|c|c|c|c|c|c|c|}
\hline & \multicolumn{2}{|c|}{ Successful group } & \multicolumn{2}{|c|}{ Failed group } & \multicolumn{2}{|c|}{ Overall } \\
\hline & $\begin{array}{l}\text { Group I } \\
\text { (13) }\end{array}$ & $\begin{array}{l}\text { Group II } \\
\text { (12) }\end{array}$ & $\begin{array}{l}\text { Group I } \\
(7)\end{array}$ & $\begin{array}{l}\text { Group II } \\
\text { (8) }\end{array}$ & $\begin{array}{c}\text { Group I } \\
(20)\end{array}$ & $\begin{array}{c}\text { Group II } \\
(20)\end{array}$ \\
\hline 1st injection relief & $\begin{array}{l}8.2 \pm 9.99 \\
\quad(13)\end{array}$ & $\begin{array}{l}5.8 \pm 6.17 \\
\quad(12)\end{array}$ & $\begin{array}{l}2.4 \pm 1.72 \\
\quad(7)\end{array}$ & $\begin{array}{l}0.4 \# \pm 1.01 \\
(8)\end{array}$ & $\begin{array}{l}6.2 \pm 8.49 \\
(20)\end{array}$ & $\begin{array}{l}3.7 \pm 5.48 \\
\quad(20)\end{array}$ \\
\hline 2nd injection relief & $\begin{array}{l}13.3 \pm 6.27 \\
\quad(13)\end{array}$ & $\begin{array}{l}14.9 \pm 13.98 \\
\quad(12)\end{array}$ & $\begin{array}{l}1.1 \pm 2.19 \\
(7)\end{array}$ & $\begin{array}{c}1.7 \pm 1.52 \\
(3)\end{array}$ & $\begin{array}{l}9.1 \pm 7.86 \\
\quad(20)\end{array}$ & $\begin{array}{l}12.3 \pm 3.83 \\
\quad(15)\end{array}$ \\
\hline 3rd injection relief & $\begin{array}{l}13.0 \pm 5.49 \\
(11)\end{array}$ & $\begin{array}{l}13.3 \pm 5.12 \\
(9)\end{array}$ & $\begin{array}{l}4.5 \pm 2.12 \\
\text { (2) }\end{array}$ & - & $\begin{array}{l}11.7 \pm 5.97 \\
\quad(13)\end{array}$ & $\begin{array}{l}13.3 \pm 5.12 \\
(9)\end{array}$ \\
\hline 4 th injection relief & $\begin{array}{l}10.9 \pm 3.27 \\
(8)\end{array}$ & $\begin{array}{l}12.6 \pm 1.13 \\
(7)\end{array}$ & $\begin{array}{c}7.5 \pm 7.78 \\
(2)\end{array}$ & - & $\begin{array}{l}10.2 \pm 4.13 \\
\quad(10)\end{array}$ & $\begin{array}{l}12.6 \pm 1.13 \\
(7)\end{array}$ \\
\hline 5th injection relief & $\begin{array}{l}11.6 \pm 1.94 \\
\quad(5)\end{array}$ & $\begin{array}{l}14.8 \pm 4.92 \\
\quad(4)\end{array}$ & - & - & $\begin{array}{l}11.6 \pm 1.95 \\
(5)\end{array}$ & $\begin{array}{c}14.8 \pm 4.92 \\
(4)\end{array}$ \\
\hline $\begin{array}{l}\text { Number of injections per } \\
\text { year }\end{array}$ & $\begin{array}{l}3.8 \pm 1.21 \\
\quad(13)\end{array}$ & $\begin{array}{l}3.4 \pm 1.08 \\
\quad(12)\end{array}$ & $\begin{array}{l}2.6 \pm 0.98 \\
\quad(7)\end{array}$ & $\begin{array}{l}1.4 \# \pm 0.52 \\
(8)\end{array}$ & $\begin{array}{l}3.4 \pm 1.27 \\
(20)\end{array}$ & $\begin{array}{l}2.6 \pm 1.35 \\
(20)\end{array}$ \\
\hline $\begin{array}{l}\text { Total relief per year } \\
\text { (weeks) }\end{array}$ & $\begin{array}{l}42.8 \pm 9.06 \\
\quad(13)\end{array}$ & $\begin{array}{l}37.8 \pm 14.00 \\
(12)\end{array}$ & $\begin{array}{c}7.0 \pm 8.08 \\
(7)\end{array}$ & $\begin{array}{c}1.0 \pm 2.14 \\
(8)\end{array}$ & $\begin{array}{l}30.3 \pm 19.49 \\
(20)\end{array}$ & $\begin{array}{c}23.1 \pm 21.36 \\
(20)\end{array}$ \\
\hline
\end{tabular}

\# indicates significant difference between groups $(P<0.05)$

\section{Discussion}

Evaluation of the effectiveness of caudal epidural injection with or without steroids in spinal stenosis associated with chronic function-limiting low back and lower extremity pain, in this randomized, doubleblind, equivalence trial, showed significant ( $\geq 50 \%$ ) reduction of pain in $65 \%$ of the patients in Group I and $55 \%$ of the patients in Group II, along with a $40 \%$ reduction in the ODI scores from baseline in $80 \%$ of the patients in Group I and 55\% of the patients in Group II. There were no changes in the employment characteristics despite the increase in functional status, but, the proportion of eligible patients for employment was small. Opioid intake was reduced significantly at 12-month follow-up in both groups.

The average procedures per year were 3 to 4 with average total relief per year of $30.3 \pm 19.49$ weeks in Group I and $23.1 \pm 21.36$ weeks in Group II. However, the patients were then divided into successful and failed groups 15 of the 40 patients assigned to the failed group and 25 to the successful group. In the analysis of the successful group, the number of procedures per year was 3 to 4 with total relief per year of $42.8 \pm 9.06$ weeks in Group I and $37.8 \pm 14.00$ weeks in Group II over a period of one year. Overall, the results are less than enthusiastic with an average relief of only 4 to 12 weeks with the initial 2 procedures and 10
Table 5. Characteristic of monitoring of weight.

\begin{tabular}{|l|c|c|c||}
\hline \hline Weight (lbs) & $\begin{array}{c}\text { Group I } \\
(\mathbf{2 0})\end{array}$ & $\begin{array}{c}\text { Group II } \\
\mathbf{( 2 0 )}\end{array}$ & \multirow{2}{*}{ P value } \\
\cline { 2 - 3 } & Mean \pm SD & Mean \pm SD & \\
\hline Initial weight & $186 \pm 55.15$ & $192 \pm 58.95$ & 0.741 \\
\hline Weight at one year & $183 \pm 56.04$ & $189 \pm 59.74$ & 0.713 \\
\hline Change & $-3.5 \pm 10.55$ & $-2.2 \pm 5.59$ & 0.480 \\
\hline
\end{tabular}

to 15 weeks in the overall population with subsequent procedures after the first 2 procedures. However, the results are much more encouraging in the successful group even though approximately one-third of the patients were in the failed. Consequently, the results of this study illustrate that if the response is fair to poor with the first 2 injections, patients will continue to exhibit an extremely poor response with future treatments and very few people continue the treatment. In fact, the total relief in the failed group over a period of one year was $7.0 \pm 8.08$ weeks in Group I in 7 patients and it was $1.0 \pm 2.14$ weeks in 8 patients in Group II - a dismal result.

This study may be criticized for the lack of a placebo group and also for publication of preliminary results in a small number of patients (20 in each group). Due to the lack of published randomized trials and 
the paucity of evidence in managing spinal stenosis with symptomatology utilizing contemporary interventional pain management practice with epidurals performed under fluoroscopic visualization and with continued follow-up rather than providing treatments initially and following them at a later date, the authors felt that it was essential to publish the results. Further, based on the sample size calculations, 20 patients is adequate. In addition, spinal stenosis which failed to respond to other conservative modalities of treatments is a refractory management problem. On the issue of placebo-control, the difficulties are insurmountable with interventional techniques in the United States. Consequently, in this evaluation, we utilized an active control group with local anesthetics and a treatment group with steroids, which is considered appropriate. Further, active control trials or pragmatic trials provide generalizability or external validity which is superior to placebo-control trials. Thus, in the modern era, practical clinical trials or equivalence/ non-inferiority trials measuring effectiveness are considered more appropriate than placebo-control trials, also known as explanatory trials, measuring efficacy (47,58-62). Practical clinical trials or equivalence/noninferiority trials are considered clinically oriented with external validity and generalizability because they show the existence of effect and also measure the effectiveness of therapies (63).

The results of this evaluation, even though less than enthusiastic and very modest, are generalizable to interventional pain management settings employing appropriate diagnostic techniques and performing the procedures utilizing contemporary methods under fluoroscopic visualization with or without steroids, by a caudal approach, with intermittent follow-up. The results of this evaluation are similar to the results in post lumbar laminectomy syndrome (54), but inferior to patients with low back pain but with or without disc herniation and/or radiculitis $(52,53)$. Further, almost one-third of the patients in this evaluation were non-responsive to caudal epidural injections, which is similar to the post surgery syndrome group but with the non-responsive proportion higher than in patients with low back pain with or without disc herniation. Even then, the results of this randomized, double-blind equivalence trial are superior and practical compared to previously published reports, especially in the light of the fact that none of them were randomized or double-blinded.

Treatment of disabling pain secondary to lumbar spinal stenosis is challenging with or without surgery.
Reports of surgery claim superiority over conservative management. However, the conservative management utilized in the past, including caudal epidural injections, has not been studied according to the criteria of contemporary interventional pain management. Consequently, the management of lumbar spinal stenosis continues to be an enigma since its first description in 1954, as a syndrome characterized by the narrowing of the lumbar vertebral canal, concurrent neurogenic spinal claudication, radicular pain, and motor weakness in the lower limbs (64). Thus, it appears that there is only a subgroup of patients with lumbar spinal stenosis that respond to surgical intervention. Similarly, there are subgroups of patients who respond to non-surgical interventions, such as caudal epidural injections. However, neither the present preliminary evaluation nor previous studies are able to delineate the features of these subgroups. Future studies must focus on these aspects.

Radiographic and anatomical findings of lumbar spinal stenosis are characterized by a narrowing of the spinal canal. Narrowing may occur in the central spinal canal, in the area under the facet joints (subarticular stenosis), or more likely, in the neural foramina. Compression of the nerve root causes symptomatic lumbar spinal stenosis, which can be characterized into several distinct entities defined by the underlying reasons for the spinal nerve root compression. In this study, we included only the patients with central stenosis either congenital or acquired. Patients with neuroforaminal stenosis were not included. Further, patients with post laminectomy and post fusion were excluded. Even though, the mechanism whereby compression of the spinal nerve roots resulting in the typical symptoms and signs of spinal stenosis has not been fully elucidated, evidence suggests that in the presence of stenosis and nerve root compression, lumbar extension reduces the cross-sectional area of the central canal, as well as the neural foramina, exerting further pressure on the venules surrounding the nerve roots. This process, in turn, leads to engorgement and ischemic nerve impairment with the ischemic mechanism accounting for typical reversibility of symptoms when patients flex their spines forward (65-72). Further, the pathophysiology of radicular pain is complex, even though mechanical compression and inflammation are considered to be the main culprits (73-81).

The underlying mechanism of epidurally administered local anesthetic and steroids is less clear than the mechanism of pain in spinal stenosis. Consequently, it has been long hypothesized that the effects of neu- 
ral blockade are dependent on the anti-inflammatory properties of corticosteroids (82-90). However, there is also emerging evidence that local anesthetics may be as equally effective as steroids in managing low back pain with or without disc herniation, secondary to post laminectomy syndrome, and of facet joint origin, and in multiple other types of nerve blocks (49-54,91101). It has been postulated that local anesthetics result in positive effects by exerting the effect on multiple pathophysiologic mechanisms involved in chronic pain, including noxious peripheral stimulation, excess nociception resulting in sensitization $(102,103)$, excess release of neural transmitters causing complex central responses $(104,105)$ and pheno-type changes considered as part of the neuronal plasticity (105-107). Further, in an evaluation in rats (108), the authors evaluated the effect of the nerve root infiltration with local anesthetic with or without steroids on mechanical allodynia. They concluded that corticosteroids may be unnecessary for nerve root blocks since they provided no additional benefit. Thus, the present evaluation indicates the lack of any significant role for the addition of steroids using a caudal approach in managing pain secondary to spinal stenosis as have other studies of low back pain $(52-54,97,99)$.

Finally, it is important to reinforce the importance of target delivery of the injectate to the optimum site of pathology. Using the blind approach to epidural procedures is often claimed to be one of the reasons for variable and failed responses. Inaccurate needle placement resulting in inaccurate placement of the drug has been reported in $20 \%$ to $38 \%$ of patients $(109,110)$. Thus, it is not hard to see the vital important of utilizing fluoroscopy to overcome this and maximize accurate delivery to the target site.

In summary, the evidence in this preliminary evaluation of a randomized equivalence trial demonstrates that caudal epidural injections with or without steroids in patients with spinal stenosis with low back and lower extremity pain provide significant pain relief and improvement in functional status.

\section{Conclusion}

This preliminary report of the results of a randomized, double-blind equivalence trial of caudal epidural injections with local anesthetic with or without steroids with chronic function-limiting low back pain and lower extremity pain has demonstrated pain relief effectiveness in $55 \%$ to $65 \%$ of the patients and improvement in functional status in $55 \%$ to $80 \%$ with 3 to 4 procedures over the course of one-year.

\section{Acknowledgments}

The authors wish to thank Sekar Edem for his assistance in search of literature and Tonie M. Hatton and Diane E. Neihoff, Transcriptionists, for their assistance in preparation of this manuscript.

\section{References}

1. Cummins J, Lurie JD, Tosteson TD, Hanscom B, Abdu WA, Birkmeyer NJ, Herkowitz $\mathrm{H}$, Weinstein J. Descriptive epidemiology and prior healthcare utilization of patients in the Spine Patient Outcomes Research Trial's (SPORT) three observational cohorts: Disc herniation, spinal stenosis, and degenerative spondylolisthesis. Spine 2006; 31:806-814.

2. Cherkin DC, Deyo RA, Loeser JD, Bush T, Waddell G. An international comparison of back surgery rates. Spine 1994; 19:1201-1206.

3. Weinstein JN, Tosteson TD, Lurie JD, Tosteson AN, Blood E, Hanscom B, Herkowitz H, Cammisa F, Albert T, Boden $\mathrm{SD}$, Hilibrand A, Goldberg $H$, Berven $\mathrm{S}$, An H; SPORT Investigators. Surgical versus nonsurgical therapy for lumbar spinal stenosis. N Engl J Med 2008; 358:794-810.

4. Deyo RA, Ciol MA, Cherkin DC, Loeser JD,
Bigos SJ. Lumbar spinal fusion: A cohort study of complications, reoperations, and resource use in the Medicare population. Spine 1993; 18:1463-1470.

5. Deyo RA, Gray DT, Kreuter W, Mirza S, 10. Jensen MC, Brant-Zawadzki MN, ObuMartin BI. United States trends in lumbar fusion surgery for degenerative conditions. Spine 2005; 30:1441-1445.

6. Ciol MA, Deyo RA, Howell E, Kreif S. An assessment of surgery for spinal steno- 11. sis: Time trends, geographic variations, complications, and reoperations. J Am Geriatr Soc 1996; 44:285-290.

7. Katz JN, Harris MB. Clinical practice. Lumbar spinal stenosis. N Engl J Med 2008; 358:818-825.

8. ECRI Health Technology Assessment Group. Treatment of degenerative lumbar spinal stenosis. Evid Rep Technol Assess (Summ) 2001; 32:1-5.

9. Boden SD, McCowin PR, Davis DO, Dina TS, Mark AS, Wiesel S. Abnormal mag- netic-resonance scans of the lumbar spine in asymptomatic subjects: A prospective investigation. J Bone Joint Surg Am 1990; 72:403-408. chowski N, Modic MT, Malkasian D, Ross JS. Magnetic resonance imaging of the lumbar spine in people without back pain. N Engl J Med 1994; 331:69-73.

Malmivaara A, Slätis P, Heliövaara $M$, Sainio P, Kinnunen $H$, Kankare J, Dalin-Hirvonen N, Seitsalo S, Herno A, Kortekangas P, Niinimäki T, Rönty H, Tallroth K, Turunen V, Knekt P, Härkänen T, Hurri H; Finnish Lumbar Spinal Research Group. Surgical or nonoperative treatment for lumbar spinal stenosis? A randomized controlled trial. Spine 2007; 32:1-8.

12. Johnsson KE, Rosen I, Uden A. The natural course of lumbar spinal stenosis. Clin Orthop 1992; 279:82-86. 
13. Atlas SJ, Keller RB, Robson D, Deyo RA, Singer DE. Surgical and nonsurgical management of lumbar spinal stenosis: Four-year outcomes from the Maine Lumbar Spine Study. Spine 2000; 25:556-562.

14. Atlas SJ, Keller RB, Wu YA, Deyo RA, Singer DE. Long-term outcomes of surgical and nonsurgical management of lumbar spinal stenosis: 8 to 10 year results from the Maine Lumbar Spine Study. Spine 2005; 30:936-943.

15. Gibson JN, Waddell G. Surgery for degenerative lumbar spondylosis. $\mathrm{Co}$ chrane Database Syst Rev 2005; 4: CDo01352.

16. Atlas SJ, Deyo RA, Keller RB, Chapin AM, Patrick DL, Long JM, Singer DE. The Maine Lumbar Spine Study, Part III: 1year outcomes of surgical and nonsurgical management of lumbar spinal stenosis. Spine 1996; 21:1787-1794.

17. Johnsson KE, Uden A, Rosen I. The effect of decompression on the natural course of spinal stenosis: A comparison of surgically treated and untreated patients. Spine 1991; 16:615-619.

18. Malmivaara A, Statis P, Heliovaara M, et al. Surgical treatment for moderate lumbar spinal stenosis: A randomized controlled trial. In: Proceedings of the International Society for Study of the Lumbar Spine, Porto, Portugal, May 30-June 5, 2004.

19. Mariconda M, Fava R, Gatto A, Longo C, Milano C. Unilateral laminectomy for bilateral decompression of lumbar spinal stenosis: A prospective comparative study with conservatively treated patients. J Spinal Disord Tech 2002; 15:3946.

20. Gibson JNA, Waddell G, Grant IC. Surgery for degenerative lumbar spondylolysis. Cochrane Database Syst Rev 2000; 3:CDo01352.

21. Airaksinen O, Herno A, Turunen V, Saari T, Suomlainen O. Surgical outcome of 438 patients treated surgically for lumbar spinal stenosis. Spine 1997; 22:2278-2282.

22. Cornefjord M, Byröd G, Brisby H, Rydevik B. A long-term (4- to 12-year) follow-up study of surgical treatment of lumbar spinal stenosis. Eur Spine J 2000; 9:563570.

23. Hansraj KK, Cammisa FP Jr, O’Leary PF, Crockett $\mathrm{HC}$, Fras $\mathrm{Cl}$, Cohen MS, Dorey FJ. Decompressive surgery for typical lumbar spinal stenosis. Clin Orthop 2001; 384:10-17.
24. Katz JN, Lipson SJ, Chang LC, Levine SA, Fossel AH, Liang MH. Seven- to 10-year outcome of decompressive surgery for degenerative lumbar spinal stenosis. Spine 1996; 21:92-98.

25. Manchikanti L. Medicare in interventional pain management: A critical analysis. Pain Physician 2006; 9:171-198.

26. Manchikanti L, Giordano J. Physician payment 2008 for interventionalists: Current state of health care policy. Pain Physician 2007; 10:607-626.

27. Specialty Utilization data files from Centers for Medicare and Medicaid Services. Medicare: www.cms.hhs.gov

28. Friedly J, Leighton C, Deyo R. Increases in lumbosacral injections in the Medicare population: 1994 to 2001. Spine 2007; 32:1754-1760.

29. Friedly J, Nishio I, Bishop MJ, Maynard C. The relationship between repeated epidural steroid injections and subsequent opioid use and lumbar surgery. Arch Phys Med Rehabil 2008; 89:1011-1015.

30. Manchikanti L, Singh V, Derby R, Schultz DM, Benyamin RM, Prager JP, Hirsch JA. Reassessment of evidence synthesis of occupational medicine practice guidelines for interventional pain management. Pain Physician 2008; 11:393-482.

31. Abdi S, Datta S, Trescot AM, Schultz DM, Adlaka R, Atluri SL, Smith HS, Manchikanti L. Epidural steroids in the management of chronic spinal pain: A systematic review. Pain Physician 2007; 10:185-212.

32. Boswell MV, Trescot AM, Datta S, Schultz DM, Hansen HC, Abdi S, Sehgal N, Shah RV, Singh V, Benyamin RM, Patel VB, Buenaventura RM, Colson JD, Cordner HJ, Epter RS, Jasper JF, Dunbar EE, Atluri SL, Bowman RC, Deer TR, Swicegood JR, Staats PS, Smith HS, Burton AW, Kloth DS, Giordano J, Manchikanti L. Interventional techniques: Evidence-based practice guidelines in the management of chronic spinal pain. Pain Physician 2007; 10:7-111.

33. Staal JB, de Bie R, de Vet HC, Hildebrandt J, Nelemans P. Injection therapy for subacute and chronic low-back pain. Cochrane Database Syst Rev 2008; 3: CDoo1824.

34. Botwin K, Brown LA, Fishman M, Rao S. Fluoroscopically guided caudal epidural steroid injections in degenerative lumbar spinal stenosis. Pain Physician 2007; 10:547-558.

35. Botwin KP, Gruber RD, Bouchlas CG, Torres-Ramos FM, Sanelli JT, Freeman
ED, Slaten WK, Rao, S. Fluoroscopically guided transforaminal epidural steroid injections in degenerative lumbar stenosis: An outcome study. Am J Phys Med Rehabil 2002; 81: 898-905.

36. Cooper G, Lutz GE. Effectiveness of transforaminal epidural steroid injections in patients with degenerative lumbar scoliotic stenosis and radiculopathy. Pain Physician 2004; 7:311-317.

37. Barre L, Lutz GE, Southern D, Cooper G. Fluoroscopically guided caudal epidural steroid injections for lumbar spinal stenosis: A retrospective evaluation of long term efficacy. Pain Physician 2004; 7:187-193.

38. Delport EG, Cucuzzella AR, Marley JK, Pruitt CM, Fisher JR. Treatment of lumbar spinal stenosis with epidural steroid injections: A retrospective outcome study. Arch Phys Med Rehabil 2004; 85:479-484.

39. Ciocon JO, Galindo-Ciocon D, Amaranath L, Galindo D. Caudal epidural blocks for elderly patients with lumbar canal stenosis. J Am Geriatr Soc 1994; 42:593596.

40. Rivest C, Katz JN, Ferrante FM, Jamison RN. Effects of epidural steroid injection on pain due to lumbar spinal stenosis or herniated disks: A prospective study. Arthritis Care Res 1998; 11:291-297.

41. Fukusaki M, Kobayashi I, Hara T, Sumikawa K. Symptoms of spinal stenosis do not improve after epidural steroid injection. Clin J Pain 1998; 14:148-151.

42. Cuckler JM, Bernini PA, Wiesel SW, Booth RE, Rothman RH, Pickens GT. The use of epidural steroids in the treatment of lumbar radicular pain. J Bone Joint Surg 1985; 67A:63-66.

43. Rosen CD, Kahanovitz N, Bernstein R, Viola $\mathrm{K}$. A retrospective analysis of the efficacy of epidural steroid injections. Clin Orthop 1988; 228:270-272.

44. Hoogmartens M, Morelle P. Epidural injection in the treatment of spinal stenosis. Acta Orthop Belg 1987; 53:409-411.

45. Moher D, Schulz KF, Altman D, for the CONSORT Group. The CONSORT statement: Revised recommendations for improving the quality of reports of parallel-group randomized trials. JAMA 2001; 285:1987-1991.

46. Piaggio G, Elbourne DR, Altman DG, Pocock SJ, Evans SJ. Reporting of noninferiority and equivalence randomized trials: An extension of the CONSORT statement. JAMA 2006; 295:1152-1160.

47. Manchikanti L, Hirsch JA, Smith HS. Ev- 
idence-based medicine, systematic reviews, and guidelines in interventional pain management: Part 2. Randomized controlled trials. Pain Physician 2008; 11:717-773.

48. Fairbank JCT, Pynsent PB. The Oswestry disability index. Spine 2000; 25:29402953.

49. Manchikanti L, Singh V, Falco FJ, Cash KA, Pampati V. Lumbar facet joint nerve blocks in managing chronic facet joint pain: One-year follow-up of a random ized, double-blind controlled trial: Clinical Trial NCTo0355914. Pain Physician 2008; 11:121-132.

50. Manchikanti L, Singh V, Falco FJ, Cash KA, Fellows B. Cervical medial branch blocks for chronic cervical facet joint pain: A randomized double-blind, controlled trial with one-year follow-up. Spine 2008; 33:1813-1820.

51. Manchikanti L, Singh V, Falco FJE, Cash KA, Pampati V. Effectiveness of thoracic medial branch blocks in managing chronic pain: A preliminary report of a randomized, double-blind controlled trial; Clinical trial NCT00355706. Pain Physician 2008; 11:491-504.

52. Manchikanti L, Cash KA, McManus CD, Pampati V, Smith HS. Preliminary results of randomized, equivalence trial of fluoroscopic caudal epidural injections in managing chronic low back pain: Part 1. Discogenic pain without disc herniation or radiculitis. Pain Physician 2008; 11:785-800.

53. Manchikanti L, Singh V, Cash KA, Pampati V, Damron KS, Boswell MV. Preliminary results of randomized, equivalence trial of fluoroscopic caudal epidural injections in managing chronic low back pain: Part 2. Disc herniation and radiculitis. Pain Physician 2008; 11:801-815.

54. Manchikanti L, Singh V, Cash KA, Pampati V, Datta S. Preliminary results of randomized, equivalence trial of fluoroscopic caudal epidural injections in managing chronic low back pain: Part 3. Post surgery syndrome. Pain Physician 2008; 11:817-831.

55. Reisine T, Pasternak G. Opioid analgesics and antagonists. In Hardman JG, Limbird LE (eds). Goodman and Gillman's: The Pharmacologic Basis of Therapeutics. McGraw-Hill, New York, 1996, p 535.

56. Hesla PE, Breivik H. Epidural analgesia and epidural steroid injection for treatment of chronic low back pain and sciatica. Tidsskr Nor Laegeforen 1979; 99:936-939.
57. Koes BW, Scholten RJ, Mens JM, Bouter LM. Efficacy of epidural steroid injections for low-back pain and sciatica: A systematic review of randomized clinical trials. Pain 1995; 63:279-288.

58. Hotopf M. The pragmatic randomized controlled trial. Adv Psychiatr Treat 2002; 8:326-333.

59. Hotopf M, Lewis G, Normand C. Putting trials on trial: The costs and consequences of small trials in depression: A systematic review of methodology. J Epidemiol Community Health 1997; 51:354358.

6o. Hotopf M, Churchill R, Lewis G. Pragmatic randomized controlled trials in psychiatry. Br J Psychiatry 1999; 175:217-223.

61. Tunis SR, Stryer DB, Clancy CM. Practical clinical trials. Increasing the value of clinical research for decision making in clinical and health policy. JAMA 2003; 290:1624-1632.

62. Roland M, Torgerson DJ. What are pragmatic trials? BMJ 1998; 316:285.

63. International Conference on Harmonisation of Technical Requirements for Registration of Pharmaceuticals for Human Use. ICH Harmonised Tripartite Guideline. Choice of Control Group and Related Issues in Clinical Trials E10. July 20, 2000.

64. Verbiest H. A radicular syndrome from developmental narrowing of the lumbar vertebral canal. J Bone Joint Surg $\mathrm{Br}$ 1954; 36:230-237.

65. Jespersen SM, Hansen ES, Høy K, Christensen KO, Lindblad BE, Ahrensberg J, Bünger C. Two-level spinal stenosis in minipigs: Hemodynamic effects of exercise. Spine 1995; 20:2765-2773.

66. Porter RW. Spinal stenosis and neurogenic claudication. Spine 1996; 21:20462052.

67. Sekiguchi M, Kikuchi S. Experimental studies of lumbar spinal stenosis. Clin Calcium 2005; 15:51-56.

68. Takenobu Y, Katsube N, Marsala M, Kondo K. Model of neuropathic intermittent claudication in the rat: Methodology and application. J Neurosci Methods 2001; 104:191-198.

69. Olmarker $\mathrm{K}$, Holm $\mathrm{S}$, Rosenqvist AL, Rydevik B. Experimental nerve root compression: A model of acute, graded compression of the porcine cauda equina and an analysis of neural and vascular anatomy. Spine 1991; 16:61-69.

70. Olmarker K, Rydevik B. Single- versus double-level nerve root compression: An experimental study on the porcine cauda equina with analyses of nerve impulse conduction properties. Clin Orthop Relat Res 1992; 279:35-39.

71. Olmarker K, Rydevik B, Holm S. Edema formation in spinal nerve roots induced by experimental, graded compression: An experimental study on the pig cauda equina with special reference to differences in effects between rapid and slow onset of compression. Spine 1989; 14:569-573.

72. Olmarker K, Rydevik B, Holm S, Bagge $U$. Effects of experimental graded compression on blood flow in spinal nerve roots: A vital microscopic study on the porcine cauda equina. J Orthop Res 1989; 7:817-823.

73. Wheeler AH, Murrey DB. Chronic lumbar spine and radicular pain: Pathophysiology and treatment. Curr Pain Headache Rep 2002; 6:97-105.

74. Hadjipavlou AG, Tzermiadianos MN, Bogduk N, Zindrick MR. The pathophysiology of disc degeneration: A critical review. J Bone Joint Surg Br 2008; 90:12611270.

75. Norimoto M, Ohtori S, Yamashita M, Inoue G, Yamauchi K, Koshi T, Suzuki M, Orita S, Eguchi Y, Sugiura A, Ochiai N, Takaso M, Takahashi K. Direct application of the TNF-alpha inhibitor, etanercept, does not affect CGRP expression and phenotypic change of DRG neurons following application of nucleus pulposus onto injured sciatic nerves in rats. Spine 2008; 33:2403-2408.

76. Okamoto K, Kobashi G, Washio M, Sasaki S, Yokoyama T, Miyake Y, Sakamoto N, Ohta K, Inaba Y, Tanaka H; Japan Collaborative Epidemiological Study Group for Evaluation of Ossification of the Posterior Longitudinal Ligament of the Spine (OPLL) Risk. Dietary habits and risk of ossification of the posterior longitudinal ligaments of the spine (OPLL); findings from a case-control study in Japan. J Bone Miner Metab 2004; 22:612-617.

77. Kobashi G, Washio M, Okamoto K, Sasaki S, Yokoyama T, Miyake Y, Sakamoto N, Ohta K, Inaba Y, Tanaka H; Japan Collaborative Epidemiological Study Group for Evaluation of Ossification of the Posterior Longitudinal Ligament of the Spine Risk. High body mass index after age 20 and diabetes mellitus are independent risk factors for ossification of the posterior longitudinal ligament of the spine in Japanese subjects: A case control study in multiple hospitals. Spine 2004; 29:1006-1010.

78. Akune T, Ogata N, Seichi A, Ohnishi I, 
Nakamura K, Kawaguchi H. Insulin secretory response is positively associated with the extent of ossification of the posterior longitudinal ligament of the spine. J Bone Joint Surg Am 2001; 83:1537-1544.

79. Genevay S, Finckh A, Payer M, Mezin F, Tessitore E, Gabay C, Guerne PA. Elevated levels of tumor necrosis factor-alpha in periradicular fat tissue in patients with radiculopathy from herniated disc. Spine 2008; 33:2041-2046.

8o. Sugiura A, Ohtori S, Yamashita M, Inoue G, Yamauchi K, Koshi T, Suzuki M, Norimoto M, Orita S, Eguchi Y, Takahashi Y, Watanabe TS, Ochiai N, Takaso M, Takahashi $\mathrm{K}$. Existence of nerve growth factor receptors, tyrosine kinase a and p75 neurotrophin receptors in intervertebral discs and on dorsal root ganglion neurons innervating intervertebral discs in rats. Spine 2008; 33:2047-2051.

81. Yamashita M, Ohtori S, Koshi T, Inoue G, Yamauchi K, Suzuki M, Takahashi K. Tumor necrosis factor-alpha in the nucleus pulposus mediates radicular pain, but not increase of inflammatory peptide, associated with nerve damage in mice. Spine 2008; 33:1836-1842.

82. Manchikanti L. Role of neuraxial steroids in interventional pain management. Pain Physician 2002; 5:182-199.

83. Manchikanti L. Pharmacology of neuraxial steroids. In Manchikanti L, Singh $\mathrm{V}$ (eds). Interventional Techniques in Chronic Spinal Pain, ASIPP Publishing, Paducah, KY, 2007; pp 167-184.

84. Byrod G, Otani K, Brisby H, Rydevik B, Olmarker K. Methylprednisolone reduces the early vascular permeability increase in spinal nerve roots induced by epidural nucleus pulposus application. $J$ Orthop Res 2000; 18:983-987.

85. Flower RJ, Blackwell GJ. Anti-inflammatory steroid induced biosynthesis of a phospholipase A2 inhibitor which prevents prostaglandin generation. Nature 1979; 278:456-459.

86. Lundin A, Magnuson A, Axelsson K, Nilsson $\mathrm{O}$, Samuelsson L. Corticosteroids preoperatively diminishes damage to the C-fibers in microscopic lumbar disc surgery. Spine 2005; 30:2362-2367.

87. Hua SY, Chen YZ. Membrane receptormediated electrophysiological effects of glucocorticoid on mammalian neurons. Endocrinology 1989; 124:687-691.

88. Hayashi N, Weinstein JN, Meller ST, Lee HM, Spratt KF, Gebhart GF. The effect of epidural injection of betamethasone or bupivacaine in a rat model of lumbar radiculopathy. Spine 1998; 23:877-885.

89. Lee HM, Weinstein JN, Meller ST, Hayashi N, Spratt KF, Gebhart GF. The role of steroids and their effects on phospholipase A2: An animal model of radiculopathy. Spine 1998; 23:1191-1196.

90. Minamide A, Tamaki T, Hashizume H, Yoshida M, Kawakami M, Hayashi N. Effects of steroids and lipopolysaccharide on spontaneous resorption of herniated intervertebral discs: An experimental study in the rabbit. Spine1998; 23:870876.

91. Wertheim HM, Rovenstine EA. Suprascapular nerve block. Anesthesiology 1941; 2:541.

92. Pasqualucci A. Experimental and clinical studies about the preemptive analgesia with local anesthetics. Possible reasons of the failure. Minerva Anestesiol 1998; 64:445-457.

93. Arner S, Lindblom U, Meyerson BA, Molander C. Prolonged relief of neuralgia after regional anesthetic block. A call for further experimental and systematic clinical studies. Pain 1990; 43:287-297.

94. Riew KD, Park JB, Cho YS, Gilula L, Patel $A$, Lente LG, Bridwell KH. Nerve root blocks in the treatment of lumbar radicular pain. A minimum five-year followup. J Bone Joint Surg Am 2006; 88:17221725 .

95. Manchikanti L. Interventional pain management: Past, present, and future. The Prithvi Raj lecture: Presented at the 4th World Congress-World Institute of Pain, Budapest, 2007. Pain Pract 2007; 7:357-371.

96. Abram SE, Likavec MJ. Pain syndromes and rationale for management. Neurogenic pain. In Raj P (ed). Practical Management of Pain. Year Book Medical Publishers, Chicago, 1986, pp 182-191.

97. Manchikanti L, Singh V, Rivera JJ, Pampati V, Beyer CD, Damron KS, Barnhill RC. Effectiveness of caudal epidural injections in discogram positive and negative chronic low back pain. Pain Physician 2002; 5:18-29.

98. Bonica JJ. Current role of nerve blocks in diagnosis and therapy of pain. In Bonica JJ (ed). Advances in Neurology, Vol. 4. Raven Press, New York, 1974, pp 445453.

99. Manchikanti L, Pampati V, Rivera JJ, Beyer CD, Damron KS, Barnhill RC. Caudal epidural injections with sarapin steroids in chronic low back pain. Pain Physician 2001; 4:322-335.

100. Raj PP. Prognostic and therapeutic lo- cal anaesthetic blockade. In Cousins MJ, Bridenbaugh PO (eds). Neural Blockade. Lippincott, Philadelphia, 1988, pp 900-901.

101. Sato C, Sakai A, Ikeda Y, Suzuki H, Sakamoto $A$. The prolonged analgesic effect of epidural ropivacaine in a rat model of neuropathic pain. Anesth Analg 2008; 106:313-320.

102. Katz WA, Rothenberg R. The nature of pain: Pathophysiology. J Clin Rheumatol 2005; 11:S11-S15.

103. Melzack R, Coderre TJ, Katz J, Vaccarino AL. Central neuroplasticity and pathological pain. Ann N Y Acad Sci 2001; 933:157-174.

104. Pasqualucci A, Varrassi G, Braschi A, Peduto VA, Brunelli A, Marinangeli $F$, Gori F, Colò F, Paladín A, Mojoli F. Epidural local anesthetic plus corticosteroid for the treatment of cervical brachial radicular pain: Single injection verus continuous infusion. Clin J Pain 2007; 23:551-557.

105. Decosterd I, Woolf CJ. Spared nerve injury: An animal model of persistent peripheral neuropathic pain. Pain 2000; 87:149-158.

106. Kawakami M, Weinstein JN, Chatani K, Spratt KF, Meller ST, Gebhart GF. Experimental lumbar radiculopathy. Behavioral and histologic changes in a model of radicular pain after spinal nerve root irritation with chromic gut ligatures in the rat. Spine 1994; 19:1795-1802.

107. Pennypacker KR, Hong JS, McMillian MK. Implications of prolonged expression of Fos-related antigens. Trends Pharmacol Sci 1995; 16:317-321.

108. Tachihara H, Sekiguchi M, Kikuchi S, Konno S. Do corticosteroids produce additional benefit in nerve root infiltration for lumbar disc herniation. Spine 2008; 33:743-747.

109. Manchikanti L, Cash KA, Pampati V, McManus CD, Damron KS. Evaluation of fluoroscopically guided caudal epidural injections. Pain Physician 2004; 7:8192.

110. Stitz MY, Sommer HM. Accuracy of blind versus fluoroscopically guided caudal epidural injection. Spine 1999; 24:13711376. 